\title{
Surgical application of fascia lata as a pericardial substitute in rabbits $^{1}$
}

\author{
Aplicação cirúrgica de fascia lata como substituto do pericárdio em coelhos
}

\author{
Gholamreza Abedi', Peyman Shahzamani ${ }^{I I}$, Mehran Shahzamani ${ }^{I I I}$, Pejman Mortazavi ${ }^{\mathrm{IV}}$, Iraj Sohrabi Haghdost ${ }^{\mathrm{V}}$, Siyamak \\ Mashhadi Rafiei ${ }^{\mathrm{VI}}$, Kamran Ghods ${ }^{\mathrm{VII}}$ \\ ${ }^{I}$ Associate Professor, Department of Surgery, Faculty of Specialized Veterinary Sciences, Science and Research Branch, Islamic Azad University, \\ Tehran, Iran. Design and supervised all phases of the study. \\ IF Fellow PhD degree, Department of Surgery, Faculty of Specialized Veterinary Sciences, Science and Research Branch, Islamic Azad University, \\ Tehran, Iran. Surgical procedures, collection and processing of study information, manuscript writing. \\ IIIAssistant Professor, Department of Cardiovascular Surgery, Shaheed Modarres Hospital, Shaheed Beheshti University of medical Sciences, Tehran, \\ Iran. Design of the study, surgical procedures, statistical analysis, manuscript writing.

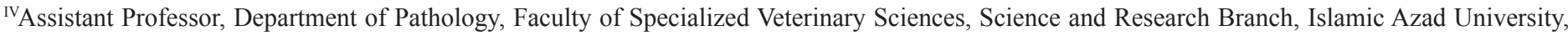 \\ Tehran, Iran. Histological analysis. \\ vProfessor, Department of Pathology, Faculty of Specialized Veterinary Sciences, Science and Research Branch, Islamic Azad University, Tehran, Iran. \\ Histological analysis.

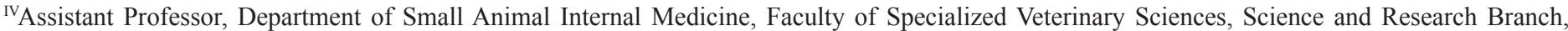 \\ Islamic Azad University, Tehran, Iran. Analysis and interpretation of data.

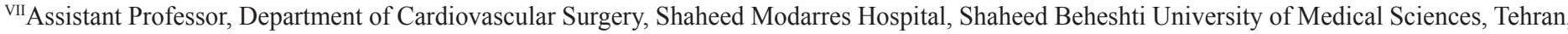 \\ Iran. Helped with technical procedures.
}

\section{ABSTRACT}

PURPOSE: To use fascia lata instead of pericardium and observe the presence of adhesions.

METHODS: Twenty rabbits were divided into two group of ten. In group A, a $1 \times 1 \mathrm{~cm}$ segment of pericardium was excised and resutured. In group B excised pericardium was substituted for autologous fascia lata.

RESULTS: In the comparison of microscopic adhesion rate between two groups A, B after eight weeks, there was no significant statistical difference.

CONCLUSION: Fascia lata is safe and it can be substituted for pericardium especially in repeat sternotomy in repairing congenital heart defects to avoid heart injury.

Key words: Fascia Lata. Pericardium. Tissue Adhesions. Rabbits.

\section{RESUMO}

OBJETIVO: Utilizar fascia lata em vez de pericárdio e observar a presencça de aderências.

MÉTODOS: Vinte coelhos foram distribuidos em dois grupos de dez. No grupo A, um $1 \times 1 \mathrm{~cm}$ de segmento de pericárdio foi retirado e resuturado. No grupo B pericárdio retirado foi substituído por fáscia lata autóloga.

RESULTADOS: Na comparação da taxa de aderência microscópica entre dois grupos A, B, após oito semanas, não houve diferença estatisticamente significante.

CONCLUSÃO: A fascia lata é segura e pode ser substituta do pericárdio, especialmente em nova esternotomia na reparação de defeitos cardíacos congênitos para evitar lesão cardíaca.

Descritores: Fascia Lata. Pericárdio. Aderências Teciduais. Coelhos. 


\section{Introduction}

Most of the patients with congenital heart defects require re-surgery and in these cases, re-surgery risk is observed clearly ${ }^{1-3}$ pericardial adhesion and mediastinal can cause damage to right ventricle, Aorta, right atrium and any aortocoronary bypass graft ${ }^{4}$.

These damages cause bleeding and reduction in right ventricle performance. Because pericardial closure especially in repairing congenital heart defects and heart edema is not possible ${ }^{5}$. Various researches explained about substances reducing adhesion formation. But most of these substances are not used clinically. In this study, microscopical effects of autologous fascia lata are assessed in reduction of adhesion and as a pericardial substitute.

\section{Methods}

Twenty white New Zealand rabbits, weighing between 2-2.5 kg were divided randomly into two groups of ten animals. In group A were the controls (a segment of pericardium was excised, and the autologous pericardium was resutured). In group B, the pericardial defect was replaced with autologous fascia lata.

All rabbits of the present research were cared according to the norms of the Islamic Azad University Faculty of Specialized Veterinary Sciences Tehran Iran laboratory of animal experimentations; this investigation was approved by the Committee of Ethics in Research with animals in Department of Veterinary Surgery too.

Anesthesia was induced with ketamin hydrochloride at a dose of $35 \mathrm{mg} \% \mathrm{~kg}$ and maintained with isofluran in oxygen. Mechanical ventilation was instituted with an approximate tidal volume set at $10 \mathrm{mg} \% \mathrm{~kg}$ body weight, with $100 \%$ oxygen, at a rate of 14-16 cycles per minute.

With the use of aseptic technique, a median sternotomy was performed. After removing fat from pericardium, its surface was seen clearly, a $1 \times 1 \mathrm{~cm}$ segment of pericardium was excised, and in group a (control) excised pericardium was resutured in its location of prolene 5-0 by single simple method. In group B (Experimental) before sternotomy, a part of rabbit fascia lata was excised with the dimension of $1 \times 1 \mathrm{~cm}$ and it was placed into normal saline. After sternotomy and excising pericardium, this segment of fascia lata was sutured instead of pericardium by single simple method of prolene 5-0.

After the surgery, the rabbits were analysed in terms of pain, weakness and the condition of urine and feces. All the rabbits received antibiotic for three days after surgery. Then, the rabbits were kept for eight weeks at similar condtions and after eight weeks, the rabbits were anesthetized like the first surgery and they underwent median sternotomy and the rate of adhesion of pericardium or fascia lata was assessed by epicardium.

Evaluation of adhesion formation between the pericardium and the epicardium were performed by the same two observers blinded to the treatment using median sternotomy approach. Adhesion formation was evaluated by macroscopic findings. The degree of adhesion was quantitatively classified from 0 to 4 .

0: without adhesion;

1: There is adhesion but it is removed easily;

2: Adhesion is removed easily by a sharp tool such as scissors;

3: Adhesion is removed with difficulty by a sharp tool;

4: Adhesion is severe as it is not possible to remove and it causes heart injury.

The Mann Whitney test was used to analyze the tenadecity score and density score of adhesion. A p value of less than 0.05 was considered significant.

\section{Results}

After eight weeks, adhesion rate is assessed in two groups. The standardized surgical procedures and the administration of the protocols were well tolerated by the animals. No adverse effects were noted, and there was no significant difference between groups with regard to weight change.

In group A (control) the least adhesion rate was 0 (Figure 1) and the highest adhesion rate was 2 and adhesion average in group A was 1.3. While in group B (Experimental), the least adhesion rate was 1 and the highest rate was 3 (Figure 2) and its average was 1.9 (Table 1).

After data collection and statistical test of Mann Whitney, $\mathrm{P}$ value was achieved as 0.094 .

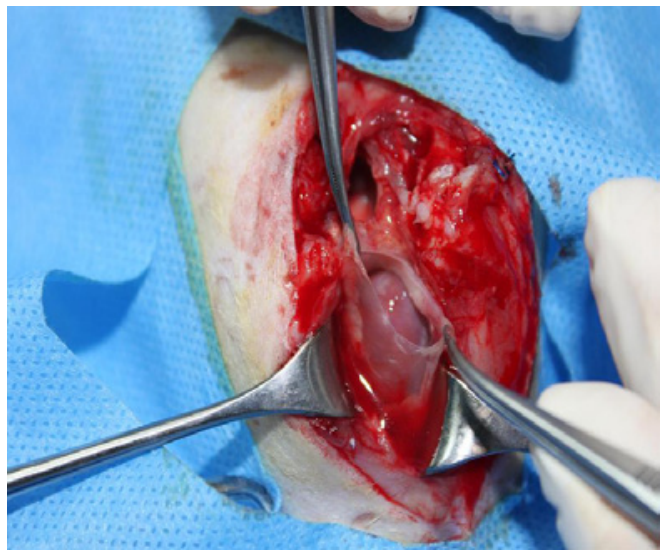

FIGURE 1 - Grade 0 adhesion in control group. 


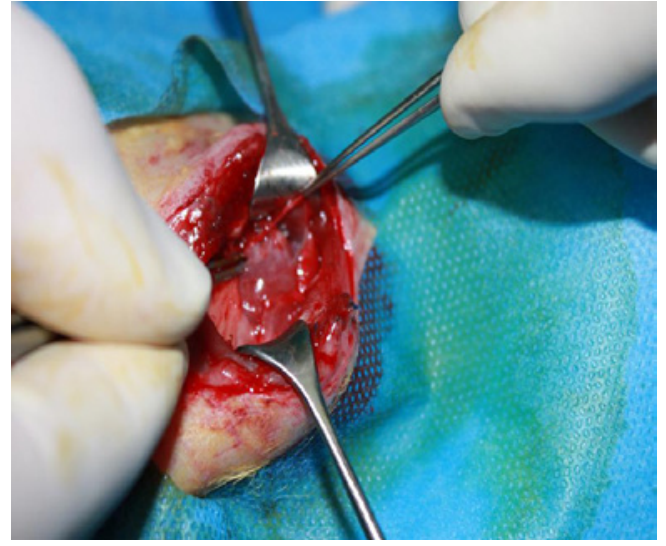

FIGURE 2 - Grade 3 adhesion in experimental group.

TABLE 1 - Adhesion rate in two experimental and control groups.

\begin{tabular}{ccccccccccc}
10 & 9 & 8 & 7 & 6 & 5 & 4 & 3 & 2 & 1 & Rabbit No. \\
\hline 1 & 2 & 1 & 2 & 2 & 2 & 1 & 1 & 0 & 1 & Control group \\
\hline 1 & 2 & 1 & 3 & 2 & 2 & 2 & 2 & 1 & 3 & Experimental group \\
\hline
\end{tabular}

\section{Discussion}

Adhesion after open heart surgery is the greatest factor in causing longer operative and perfusion times, bleeding and injury to the heart or great vesels ${ }^{6}$.

Many experimental and clinical attemption have been made to solve this problem by using different type of pericardial substitutes. The materials for these substitutes have include silicon rubber $^{7}$, polyurethane ${ }^{8}$, E-PTFE sheet ${ }^{7,9,10}$, Dacron ${ }^{11,12}$ and dura mater $^{13}$.

Fascia lata is one of the strongest fascias of the body. Histologically, fasica lata is composed of a collagen matrix with fibroblasts and elastic tissues. The relative acellularity and low nutritional requirements make it suitable for grafting. This fascia is used in reconstructive procedures such as repairing dog diaphragm $^{14}$, in correction of congenital ptosis of eyebrow ${ }^{15}$, in curing Cruciate ligament injury ${ }^{16}$ and as substitute for Mitral and Aortic valves ${ }^{17}$ and in all the mentioned items had good results.

In our study, adhesion rate percent in control group in zero rate was $\% 10$ and grade $1: 50 \%$ and grade $2: 40 \%$. But this percentage is experimental group is in grade $1: 30 \%$, grade $2: 50 \%$, grade $3: 20 \%$. These results show that statistically there is not significant difference between these two groups. Indeed, this study showed that fascia lata can be a good substitute for pericardium and it can bear the pressure of heart movement well. This patch can keep its existence in the new location.

\section{Conclusions}

The fascia lata can be used as a pericardial substitute in rabbit model. But various researches are required and this can be a good method for pericardial substitute.

\section{References}

1- Mac Manus Q, Okies JE, Starr A. Surgical considerations in patients undergoing repeat median sternotomy. J Thorac Cardiovasc Surg. 1975;69:138-43.

2- Dobell ARC, Jain AK .Catastrophic hemorrhage during redo sternotomy. Ann Thorac Surg. 1984;37:273-81.

3- Jacobs JP, Raju S, Iyer Mch. Expended PTFE membrance to prevent cardiac injury during resternotomy for congenital heart disease. J Ann Thorac Surg. 1996;62:1778-82.

4- Okuyama N, Catherine Y. Reduction of retrosternal and pericardial adhesion with rapidly restorable polymer films. J Ann Thorac Surg. 1999;68:913-8.

5- Siga Y, Takai S. Attenuation of adhesion formation after cardiac surgery with a chymase inhibitor in a hamster model. J Thorac Cardiovasc Surg. 2004;127:72-8.

6- Sakuma K, Iguchi A. Closure of the pericardium using synthetic bioabsorable polymers. J Ann Thorac Surg. 2005;80:1835-40.

7- Laks H, Hammond G, Ceha AS .Use of silicon rubber as a pericardial substitute to facilitate reoperation in cardiac surgery. J Thorac Cardiovasc Surg. 1981;82:88-92.

8- Master CA, Comas JV, Ninot S, et al. The use of polyetherurethane urea and polytetrafluoroethylene membrane for pericardial closure: initial clinical results. Thai J Surg. 1986;125-87.

9- Revuelta JM, Gracia-Rinaldi R, Val F, Crego R, Duran CM. Expanded polytetrafluoroethylene surgical membrane for pericardial closure. J Thorac Cardiovasc Surg. 1985;89:451-5.

10- Minale C, Hollweg G, Nicol S, Mittermayer C, Messmer BJ. Closure of the pericardium using expanded polytetrafluoroethylene GORETEX-Surgical Membrane: clinical experience. J Thorac Cardiovasc Surg. 1987;35:312-5.

11- Youmans CR, White J, Derrick JR. The prevention of pleural and pericardial adhesion with silastic. J Thorac Cardiovasc Surg. 1968;55:383-8.

12- Mazuji MK, Lett JC. Siliconized Dacron as a pericardial patch. Arch Surg. 1963;87:104-7.

13- Bonnabeau RC, Armanious AW, Tarnay TJ. Partial replacement of pericardium with dura substitute. J Thorac Cardiovasc Surg. 1973;66:196-201.

14- Suzuki K, Takahashi T, Itou Y, Asai K, Shimota H, Kazui T. Reconstruction of diaphragm using autologous fascia lata: an experimental study in dog. J Ann Thorac Surg. 2002;74:209-12.

15- Zandi AR. Harvesting fascia lata for brow suspension procedure via two small skin incision. JRMS. 2006;11(6):396-9.

16- Bosworth DM, Bosworth BM. Use of fascia lata to stabilize the knee in case of ruptured crucial ligament. J Bone Joint Surg Am. 1936;18:178-9.

17- Dalichau H, Gonzalez-Lavin L, Ross DN. Autologous fascia lata transplantation for heart vale replacement. Thorax. 1972;27:18-22. 
Abedi Get al.

\section{Correspondence:}

Peyman Shahzamani

Department of Veterinary Surgery

Faculty of Specialized Veterinary Sciences

Sciences and Research Branch

Islamic Azad University

Hesarak, Tehran, Iran

Phone: 0098-09133182152

peyman_sh_dvm@yahoo.com

Received: March 16, 2012

Review: May 18, 2012

Accepted: June 19, 2012

Conflict of interest: none

Financial source: none

1 Research performed at the Department of Surgery, Faculty of Specialized Veterinary Sciences, Science and Research Branch, Islamic Azad University, Tehran, Iran. 